\title{
SCIENCE AND RELIGION IN THE WRITINGS OF DR WILLIAM FULKE
}

\section{RichaRD BAUCKHAM*}

IN the course of the debate over the relationship between Puritanism and the scientific revolution in England, it is surprising that little attention has been given to the writings of William Fulke $\left(1_{537-89)}\right.$. They provide the material for a case-study of a kind which is possible in few other writers of the Elizabethan period, for Fulke is a rare example of a writer who was equally competent in natural philosophy and in theology. His early scientific publications were as significant a contribution to Elizabethan thought as the voluminous theological works that later earned him his reputation as the outstanding English theologian of his generation. Thomas Fuller (referring to Fulke's work on meteorology) wrote that 'his endeavours ascended from the middle region of the air to the highest heavens, when he became a pious and solid divine'; but while this accurately describes the sequence of his published work, we may add that his Protestant convictions were never far from his mind in the scientific works and also that his wide interests in natural philosophy remained with him long after his publications had become almost exclusively theological. Moreover, his reputation as successor to John Jewel in the leadership of Anglican apologetic against Rome came only with later years and growing conservatism; in the years $1563-72$ he was most widely known as a radical Puritan activist. The biographical link between his science and his religion is provided by his earlier career, for, so far as we can tell, his scientific interests and his radical Protestant convictions grew simultaneously and in the same intellectual context.

Fulke was admitted as a scholar to St John's College, Cambridge, in November 1555 , and after graduating in January $155^{8}$ entered Clifford's Inn, one of the Inns of Chancery attached to the Inner Temple. In November 1560 he was admitted to the Inner Temple, but by that time he had already published his Antiprognosticon, an attack on astrology, and it was probably clear that the law was no longer his primary interest, if it had ever been. One manuscript work survives from his time at Clifford's Inn and indicates the scope and nature of his studies. The work is a translation of Littleton's Tenures into Latin, but in the dedication Fulke explains how, in a period of acute depression following an attack of the plague, he sought relief in a whole series of studies: classical poetry, geography, meteorology, geometry, astronomy, music. Returning at last to the study of Littleton's legal textbook he was at once repelled by the barbarism of the

- St John's College, Cambridge.

- Thomas Fuller, The history of the worthies of England, ed. P. A. Nuttall (London, 1840),

THE BRITISH JOURNAL FOR THE HISTORY OF SCIENCE Vol. 8 No. 28 (1975) 
legal French in which it was written: hence his concern to translate the work into a language more palatable and more fitting for the subjectmatter. ${ }^{2}$ These were the sentiments of the humanist rather than the lawyer, and recall the plans of Starkey and Morison in the 153 os to replace legal French. 3 Fulke gave up the law and returned to St John's in late 1562 or early $5_{5} 6_{3}$, intending to study theology and oriental languages. 4

Most of his wide academic interests may be traced back to these five years at the Inns, but the importance of his earlier undergraduate career at St John's is more dubious. The college had declined much from its heyday of Erasmian learning and Protestant faith in the time of Roger Ascham and Sir John Cheke, and Mary's accession had brought about the departure of some twenty Fellows from the college. There is some evidence, however, that the college's fine tradition of Greek and Hebrew learning was not entirely broken, 5 and there may have been some remnants of a less vigorous tradition of scientific curiosity. 6 The origins of Fulke's Protestant convictions are even more obscure: what little evidence there is suggests that the Inns enjoyed considerable freedom of religion under Mary, 7 but we cannot tell whether Fulke was already a covert Protestant at St John's. It seems most natural to connect his Protestantism with his wider intellectual interests, for by 1560 he was already acquainted with Hebrew as well as Greek: ${ }^{8}$ as in the case of some of the early Protestants, his study of the original languages of Scripture may well have been a gateway to Protestant belief. A glance at the group of friends who in 1560 contributed verses to one or other version of his Antiprognosticon suggests membership of a circle that shared both humanist intellectual interests and Protestant faith. Two of these had been undergraduate contemporaries at St John's: John Lucas (a son of his namesake, Edward VI's Master of Requests) 9 and William Painter (who translated Fulke's Antiprognosticon into English, 10 later made his name as a translator of Italian novelists, and was ordained

2 Bodleian Library, MS. Rawlinson C. 673, dedication (unpaginated).

3 See Thomas Starkey, A dialogue between Reginald Pole and Thomas Lupset, ed. K. M. Burton (London, 1948), p. 174; G. R. Elton, 'Reform by statute' (Raleigh lecture, 1968), Proceedings of the British Academy, liv (1968), $177,179$.

4 Further biographical detail will be found in $R$. Bauckham, 'The career and thought of Dr William Fulke (1537-1 589)' (Cambridge University Ph.D. thesis, 1973).

5 Remaining Fellows included Bartholomew Dodington (later Regius Professor of Greek) and Miles Buckley (whose inventory, 1559, included an impressive list of Hebrew books).

6 See P. J. French, Fohn Dee: the world of an Elizabethan magus (London, 1972), pp. 23-4; W. S. Hudson, Fohn Ponet (1516?-1556): advocate of limited monarchy (Chicago, 1942), pp. 12-1 3 . 7 R. J. Fletcher, 'The Reformation and the Inns of Court', Transactions of the St Paul's Ecclesiological Society, v (1905), 154 .

1 W. Fulke, Antiprognosticon that is to saye, an invective agannst the vayne and unprofitable predictions of the astrologians, trans. W. Painter (London, 1560), sigs.Biiiir, Bvii", Bviii ${ }^{7}$, Gviv. In this article William Painter's English translation of Fulke's Antiprognosticon will be cited as Antiprognosticon; Fulke's original Latin version as Antiprognosticon contra praedictiones.

- References to John Lucas junior at the Inner Temple in 1560 and 1563 are in F. A. Inderwick, $A$ calendar of the Inner Temple records (London, 1896), i. 160, 213 . The index wrongly confuses him with John Lucas senior.

so It has been stated (DNB article on Painter, followed by H. G. Dick, 'The authorship of

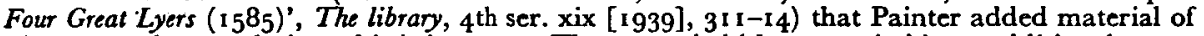
his own to the translation; this is incorrect. The appended 'short treatise' is an additional, more popular work by Fulke himself. 
in 1560 ). A third, Henry Bennet, is otherwise known only for his single published work, the lives of Luther, Oecolampadius, and Zwingli.n

Besides two almanacs which are no longer extant, ${ }^{12}$ Fulke's years in London produced three published works. One of these, The philosophers game ( $5_{5}{ }_{3}$ ), a collaborative effort with Ralph Lever (a Marian exile from St John's), ${ }_{3} 3$ was a version of the medieval arithmetical game rithmomachy and was translated from the French version of Claude de Boisière (Buxerius). ${ }^{14}$ Games of this kind were popular in Elizabethan England, and Fulke seems to have been attracted to the idea of combining edification with relaxation. He later published two other board-games of

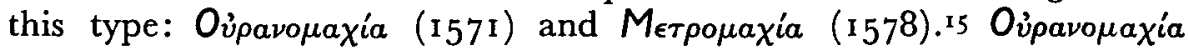
was an astrological game, with pieces representing the heavenly bodies moved, in approximation to their actual movements, across a very large board representing two zodiacs. Fulke's intention was to provide edifying recreation for students, and, despite its defects as a game (the rules are more effective in acquainting the player with astrological information than in providing much scope for his skill), it proved very popular.

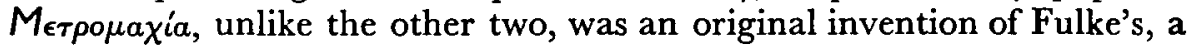
geometrical game which testifies to his mathematical interests. Part of the preface was devoted to justifying the work as an encouragement to the study of mathematics, and extravagantly Fulke hoped that it would contribute to a revival of the 'mathematical spirits of Architas and Archimedes'. Following contemporary esteem for music among the mathematical sciences, he went on to lament the decay of music in his time, by comparison with the music of classical antiquity; the rarity of genuine 'musici' he linked with the decay of mathematics. ${ }^{16}$ His continuing concern about the study of geometry in Cambridge is reminiscent of John Dee's in his preface to the English version of Euclid, where the link with musical studies was also emphasized. ${ }^{7} 7$

More significant, however, were Fulke's two major works on natural philosophy: Antiprognosticon (1560) and $A$ goodly gallerye ( $\left.{ }^{563}\right) \cdot{ }^{18}$ These sprang naturally out of his broad humanistic interests; but equally they sprang from the religious motivations which by 1560 had become dominant in his studies. To his own satisfaction he resolved any question of a

"H. Bennet, $A$ famous and godly history (London, 1561 ).

"See note 40, below.

13 W. Fulke and R. Lever, The most noble auncient, and learned playe, called the philosophers game (London, 1563 ). On the joint authorship and their subsequent dispute, see E. Rosenberg, Leicester, patron of letters (New York, 1955), pp. $40 \mathrm{ff}$.

14 H. J. R. Murray, A history of board-games other than chess (Oxford, 1952), p. 84.

I5 OYPANOMAXIA, hoc est, astrologorum ludus (London, 1571); some copies are dated 1572. METPOMAXIA sive ludus geometricus (London, $157^{8}$ ).

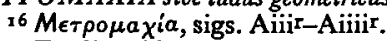
biiir

17 Euclid, The elements of geometrie, trans. H. Billingsley (London, 1571), sigs. Aiiiir, biiv-

"A goodly gallerye with a most pleasaunt prospect, into the garden of naturall contemplation, to behold the naturall causes of all kynde of meteors. This was the title of the first edition (London, 1563). My references are all to the 1602 edition, which was entitled $A$ most pleasant prospect (etc.). Bibliographical details of editions up to 1670 will be found in Bauckham, op. cit. (4), p. 414. - 
conflict between science and religion. The glory of God could be seen in the study of the natural creation, and the pattern of causation in a divinely ordered universe was as knowable to the scientist as the pattern of revealed truth was to the theologian. Indeed, one of the most striking features of $A$ goodly gallerye (Fulke's meteorological work) is the confidence with which scientific explanations are advanced. Seneca, one of Fulke's major sources, could happily concede the mysteriousness of meteorological phenomena in a world whose God was unknowable, ${ }^{19}$ and in the sixteenth century this scepticism about the confident statements of natural philosophers was expressed by Erasmus, ${ }^{20}$ among others, and passed, as a more moderate emphasis on the limitations of human knowledge, into some Elizabethan religious thought. ${ }^{21}$ Fulke, however, gave explanations for the most extraordinary of phenomena with the same unflagging dogmatism he was later to employ in defence of the Protestant faith against Romanism. The possibility of rational comprehension both of the natural world and of the revealed Word (though the latter required spiritual illumination too) was an assumed basis from which Fulke worked and fought in both realms to defend truth against superstition and pretended claims to knowledge which lacked solid foundation. He moved from science to theology as his competence and situation changed: but in debate with Edmund Campion in $158 \mathrm{r}$ he was still ready to take issue on a scientific question in the midst of theological disputation.22

In his Antiprognosticon Fulke attacked the prevalent practice of astrology. The attitude of Renaissance humanism to this subject was more divided than that of Protestant theology (though Melanchthon, beloved of astrological apologists, is clear evidence of the division in the theological ranks too). The anti-astrological writings of Pico della Mirandola had provided the foundation for a humanist tradition of opposition which passed into English writers such as Thomas More and Roger Ascham, ${ }^{23}$ but on the other hand it is clear that astrology, with its claims to provide a comprehensive system of understanding the world, had a strong appeal to Tudor intellectuals 24 and that popular interest increased appreciably during the century. 25 In undertaking a full-scale attack on astrology Fulke

2, E.g. Seneca on comets: 'when God, the greatest part of the universe, is an unknown God, we are surprised, are we, that there are some specks of fire we do not understand?', in Quaestiones naturales, VII. xoxi; trans. J. Clarke (London, 1910), p. $3^{\circ} 5$.

${ }_{20}$ 'The scientists... postulate causes for lightning, winds, eclipses, and other inexplicable things never hesitating for a moment, as if they had exclusive knowledge about the secrets of nature', in The praise of folly, in J. P. Dolan (ed.), The essential Erasmus (New York, I964), p. 142.

${ }^{21}$ E.g. John Jewel, Works (Cambridge: Parker Society edition, 1845-50), iv, 1183 . Cf. Paul Kocher, Science and religion in Elizabethan England (San Marino, California, 1953), pp. 72 ff.

${ }^{22}$ Harleian MS. 422, fol. $166^{\mathrm{v}}$; A. Nowell and W. Daye, $A$ true report of the disputation had in the Tower (London, 1584 ), sig. Niv ${ }^{r}$.

${ }^{3}$ D. C. Allen, The star-crossed Renaissance (New York, 194I), chapter I, and pp. 101-2; H. G. Dick, in Thomas Tomkis, Albumazar, ed. H. G. Dick (Berkeley, 1944), pp. 2 I-2.

${ }^{24} \mathrm{~K}$. Thomas, Religion and the decline of magic. Studies in popular beliefs in sixteenth and seventeenth century England (London, 1971), pp. 291-2, 324-32; Kocher, op. cit. (21), pp. 202-3.

25 Thomas, op. cit. (24), p. 288. 
was well aware of the audacity of his enterprise, ${ }^{26}$ and in the additional treatise which he appended to Painter's translation he referred to the malice that his work had called forth from astrologers. ${ }^{27}$ In England his work, as he correctly pointed out, ${ }^{28}$ had no precedent, though he acknowledged his debt to Peter Dacquet's attack on the use of astrology in medicine ${ }^{29}$ and was aware that the English Reformers had attacked astrology.30 From the attacks of Coverdale, Hutchinson, and Hooper, ${ }^{31}$ however, his work differed not only in sheer size but also in being argued chiefly in terms of natural philosophy rather than of theology. In this respect (since little originality can be claimed for his material and much of it derives from Pico32) he was dependent on Renaissance thought rather than on Protestant theology.

The immediate impetus for his attack seems to have come from the effect on the popular mind of the prognostications for I559, especially those of Nostradamus, which seemed to predict dire consequences if the Reformed religion were re-established in England. As Francis Coxe explained,

the whole realm was so troubled and so moved with the blinde enigmatical and develish prophesies of that heaven gazer Nostradamus, in such sort, that even those whiche in their heartes coulde have wisshed the glory of God and his worde most florishing to be established: were broughte into such an extreme coldnes of faythe, that they doubted God hadde forgotten hys promise, yea, they hong so choysly betwene the heavenly fountayne of hope, and the bottomlesse pytte of utter desperation: that in doubt it was to which they woulde adhere or stick, so great was thinfection of this pestilentiall poysoned lying prophesies. 33

Hence the six astrologers whom Fulke singled out for attack (Michael Nostradamus, William Cuningham, Thomas Hill, Henry Low, Lewes Vaughn, Anthony Ascham34) had all produced such prognostications, though Fulke also took pains to refute the defence of astrology contained in a (no longer extant) Invective by Cuningham.35 This context has been

:6 Antiprognosticon, sig. Aiiiir.

27 Ibid., sig. Diir. A strong attack on Fulke's work appeared in Latin verses by Edward Dering prefaced to M. Palingenius, The firste syxe bokes of the zodiake of life, trans. B. Googe (London, 1561 ).

28 Antiprognosticon, sig. Aiiiiv.

9 P. Dacquet, Almanack novum et perpetuum (London, 1556).

$3^{\circ}$ Antiprognosticon, sig. Div.

${ }^{31}$ For Coverdale, see Thomas, op. cit. (24), p. $3^{6} 7 \mathrm{n}$. See also Roger Hutchinson, The image of God (1550), in Works (Cambridge: Parker Society edition, 1842), pp. 77-8; John Hooper, $A$ declaration of the ten holy commandementes (1548?), in Writings (Cambridge: Parker Society edition, 1843 ), i. 308-9, 328-33.

${ }^{32}$ According to Allen, op. cit. (23), p. I I 1, Fulke's work contains 'no arguments that cannot be read in some continental polemic'.

$33 \mathrm{~F}$. Coxe, $A$ short treatise declaringe the detestable wickednesse of magicall sciences (London, $156 \mathrm{r}$ ), sigs. Aiv $-\mathrm{Av}^{\mathbf{r}}$.

34 Antiprognosticon, sig. $\mathrm{Bi}^{\mathrm{r}}$.

35 Ibid., sig. Cviv. The work was probably an appendix or preface to a prognostication. Cuningham was distinguished by Fulke as 'vir alioqui doctus et probus, sed huius artis non vulgaris professor' (Antiprognosticon contra praedictiones, sig. B4 ${ }^{\mathbf{T}}$ ). 
discussed in detail by S. V. Larkey, ${ }^{36}$ and Fulke's arguments have been well summarized by D. C. Allen. 37 No attempt at summary needs to be attempted here: rather some aspects of the work will be discussed in relation to Fulke's wider scientific interests.

Fulke was no ignoramus in astrological learning. $3^{8}$ It seems likely that he himself had first studied astrology with serious intentions before becoming convinced of its worthlessness. Probably from personal experience there arose the desire to prevent others from similarly wasting their time:

seeyng many whiche are desirous to learne the sciences, to have also muche sette by this celestiall divination, I thought good to admonishe them by this litle treatise, that they laboure not in vayne. 39

It is curious, however, that outside the Antiprognosticon there is evidence for a less unambiguous attitude to astrology than is expressed there. In ${ }_{1} j^{6}$ I and ${ }_{15} 6_{3}$ Fulke published two (no longer extant) works entitled 'an almanack and prognostication' : $4^{\circ}$ but these may be regarded as works of a non-astrological nature. The regular Elizabethan almanac frequently confined its astrological prediction to little more than weather-forecasting and providing a table of good days for blood-letting; $;^{41}$ and there were those ('certaine reformed Almanacks' as John Chamber called them42) which excluded even these applications of astrology (to which Fulke took exception in the Antiprognosticon). In view of the universal popularity of almanacs, it may have been his deliberate intention to provide an alternative. Certainly in the mid-156os his opposition to astrology is clear, for he included anti-astrological quotations in his research notes from the Church Fathers, which were otherwise almost exclusively proof-texts against popery.43

In 1566 , however, he transcribed and edited 44 and in $157^{1}$ published

${ }^{36} \mathrm{~S}$. V. Larkey, 'Astrology and politics in the first years of Elizabeth's reign', Bulletin of the Institule of the History of Medicine, iii (1 935), 17 1-86.

37 Allen, op. cit. (23), pp. 108-12.

$3^{3}$ Antiprognosticon, sigs. Aiiiiv, Diiiir, Dviiv. Among the standard works to which Fulke referred were Joannes Sacro Bosco, Spherae tractatus; Bernard Sylvestris, De mundi universitate; John Indagine (Jean de Hayn), Introductiones apotelesmaticae.

39 Antiprognosticon, sigs. Aiiiiv $-\mathrm{Av}^{\mathrm{r}}$.

40 Entered in the Stationers' Register for $1560-1$ and $1562-3$. See E. Arber (ed.), A transcript of the registers of the Company of Stationers (London, 1875 ), i. 1 53, 205; cf. E. Bosanquet, English printed almanacks (London, 1917), pp. 194-5. Larkey, op. cit. (36), p. 174, regarded these entries as references to the Antiprognosticon (for which otherwise no entry occurs); but on this suggestion it is difficult to explain the second entry, which has a different publisher. No second edition of the Antiprognosticon is known.

4I For example, Francis Coxe's Prognostication for 1566 confines its astrological material to weather-forecasting and medical advice: these, though repudiated by Fulke, were widely accepted by theologians as legitimate uses of astrology, and so this work of Coxe's ought not to be seen as so complete a reversal of his attack on astrology in $A$ short treatise as has been supposed: see $D \mathcal{N B}$ article on Coxe, and Bosanquet, op. cit. (40), p. 39. For a summary of the contents of the average Elizabethan almanac, see Kocher, op. cit. (21), pp. 208-9.

${ }^{2}$ John Chamber, $A$ treatise against judicial astrologic (London, 1601 ), p. 2.

43 Trinity College, Dublin, MS. 235.

44 Oipavopa ${ }^{1}$ la, sig. Aivv. 
the astrological game Oujpavouaxía, which was explicitly designed to impart knowledge of 'astrologia'. The introduction betrays no attempt to distinguish, as Fulke had done in the Antiprognosticon, between astrology and astronomy.45 The game employs all the standard astrological significations of the planets, their classification as masculine and feminine, their various 'aspects' as lucky and unlucky, their places in the constellations ('domicilium', 'altitudo', 'dejectio'), and so on: by no means all of this could pretend to be merely astronomical knowledge of the kind which Fulke commended in the Antiprognosticon, and some of it he had explicitly condemned. The same inconsistency is reflected in passages in Trinity College, Dublin, MS. ${ }^{6} 6$ (passages probably written by Fulke in the I570s): one passage of strongly hermetic character on astrological talismans $4^{6}$ and another passage on Ptolemy where Fulke's opposition to astrology led him apparently to speak even of strictly astronomical study as tending to detract from faith.47 In 1582 Richard Harvey, then a Fellow of Pembroke Hall when Fulke was Master of the college, and concerned to defend his own practice of astrology as consistent with his intentions of professing divinity, alleged Fulke (along with Melanchthon, Chytraeus, Dr Adam Squire, and others) among those 'who being professed in Divinitie to their own speciall commendation, and the generall benefite of the Church, were not afterward ashamed both to defend, and to practice Astrologie'. $4^{8}$ With due allowance for the ambiguity of the word 'astrology' and for that fact that Trinity College, Dublin, MS. I6 6 is a haphazard compilation, more uncritically dependent on other authorities than most of Fulke's work, we cannot ignore the indications that Fulke's attitude to the subject became more lenient in the years after the publication of the Antiprognosticon.49 But unfortunately the evidence is too scattered for us to be able to track with any real confidence the direction in which Fulke's scientific thinking was moving. On the basis of the evidence just given, it seems a reasonable guess (though it cannot be much more) that after about ${ }_{15}{ }_{5}$ Fulke allowed himself to come rather more under the influence of Neoplatonic elements in contemporary scientific thought. A further suggestion of this occurs in $158 \mathrm{I}$, when in discussion with Campion he apparently cited Trismegistus as an authority-though he seems later to

45 Ibid., sig. Bir.

${ }^{6}$ Trinity College, Dublin, MS. 165, fol. 230rv. This manuscript is a seventeenth-century edition of a sixteenth-century work which in all probability is by Fulke; for the date of the original $1570-9$ and the complex problem of authorship, see the discussion in Bauckham, op. cit. (4), bibliographical note 2 .

${ }_{17}$ Trinity College, Dublin, MS. 165 , fol. $148 \mathrm{v}$.

$4^{8} \mathrm{R}$. Harvey, An astrological discourse (London, 1583 ), sig. If iiir ${ }^{\mathrm{r}}$.

49 Allen's opinion was that Fulke's 'seeming incongruity of attitude and performance is ... removed by noticing that Fulke, like many of the opponents of astrology, was against only the judicial phases of the science'; see Allen, op. cit. (23), p. 106. But this explanation fails to take account of the full force of the argument in the Antiprognosticon, and moreover Allen ignored the O $\rho_{\alpha \nu} \mu^{\prime} \chi^{\prime} a$ and did not know of Trinity College, Dublin, MS. 165. The astrological signs and properties which feature prominently in the Otpavopaxia are ridiculed as entirely spurious in the Antiprognosticon. 
have thought this rash and had the reference omitted from the published version of the debate.50

The effect of Neoplatonism on Fulke might have been to shake his confidence somewhat in the boundary between astronomy and astrology as he drew it in the Antiprognosticon, a boundary by no means as clearly fixed in the judgement of contemporaries as he then seemed to think. $5^{\mathrm{I}}$ This is obvious enough even from the confusion of terminology.52 Astrology was so embedded in contemporary medical practice that few of its opponents went so far as to deny its validity in this sphere: Fulke's denial that there were astrologically good days for blood-letting had no precedent except in Dacquet, 53 and his refusal to allow for weather-prediction by astrological means was also unusual. The predominant concern of both humanist and Protestant opponents of astrology was to assert the independence of human reason and will from domination by the stars, but considerable room might be left for the influence of the heavens on the natural world and the physical aspects of man's nature. Fulke, while not disposed to deny Aristotle's dictum that 'All higher thynges woorketh in the lower bodies', 54 concentrated his attack on denying that astrology had any reliable means of detecting the influence of the stars. 55 The effect of this was to undercut the scientific basis of all astrological method, thereby disallowing its validity in all fields and making the Antiprognosticon one of the most devastating of all sixteenth-century anti-astrological works. Its very extremism may make Fulke's later, more lenient attitude no great surprise. The Antiprognosticon was a work of youthful intellectual bravado, and doubtless it was moderation, together perhaps with closer knowledge of hermeticism, which later prevailed over the sweeping exclusion of everything 'astrological' and led Fulke to redraw the boundary between the true and the spurious sciences of the stars. But the Antiprognosticon is more than effective polemic; it has a distinctive intellectual stance that is also to be found in $A$ goodly gallerye and may therefore fairly be identified as characteristically Fulke's.

5० The reference to Trismegistus is in one of the Catholic manuscript accounts (Harleian MS. 422 , fol. $166^{v}$ ) but omitted in the Protestant account of the dispute which John Field prepared and Fulke approved; see Nowell and Daye, loc. cit. (22).

${ }^{5}$ Antiprognosticon, sig. Aviv: 'the difference of these artes, I thynke is manifestly knowen to all men'.

$5^{2}$ Calvin spoke of astronomy as true astrology. Coxe, op. cit. (33), sig. Aviv, opposed 'the simple knowledge of Astrologie' to 'the curious parts of Astrologie'. Hooper, op. cit. (3I), i. 33I, used 'astrologer' and 'astronomer' in precisely the opposite senses to those in Fulke's (and the normal) usage.

53 Antiprognosticon, sig. Biv. Gf. Calvin, An admonicion against astrology, trans. G. Gylby (London, I56I), sig. Dir.

54 Aristotle, Meteorologica, I. ii ; quoted in Antiprognosticon, sig. Bviiiv.

5s This is not too different from Pico's attitude, as described in D. P. Walker, Spiritual and demonic magic from Ficino to Campanella (London, 1958), p. 56: 'Pico insists that celestial influences are only a universal cause of sublunar phenomena; all specific differences of quality or motion are due to differences inherent in the receiving matter or soul'. Celestial influences could therefore neither be controlled for specific effects, as in the magical tradition, nor predicted, as in the kind of astrology which Fulke is more directly attacking. 
Of course, Fulke had nothing but praise for the pure science of astronomy $5^{6}$ ('of all humayn sciences it is the most divine') and he justified its study sufficiently by the Aristotelian notion of knowledge as an end in itself. 57 It was also useful in so far as the stars served as signs for the calculation of times. This, for Fulke, was the meaning of the supposed astrological proof-text Genesis, i. I4: the stars were signs, but not causes, of the seasons. $5^{8}$ For this reason astronomical knowledge might be beneficial to the physician: 'Not that the starres doo foretell hym of any thynge, but that their risyng or fallyng is coincident with such state of time'.59 The physician, the farmer, the mariner had all learned by observation the usefulness of the heavens as signs of times and seasons; but they had not discovered and could not discover astrological rules for, for example, specific long-term weather predictions or show that sickness and health depended on the stars. 60 Other writers such as Calvin allowed for rather more actual causation in these matters, but the emphasis on the argument that the stars were signs for knowing times rather than causes whose specific effects could be predicted was fairly general. ${ }^{6 \mathbf{r}}$

The primary contemporary theological argument against astrology ${ }^{62}$ was its supposed determinism. The theologians could not think of man as under the control of the heavens: 'God made man to rule, and not to be ruled; and all creatures should serve him.' Some influence on the physical side of man's nature night be allowed, 'but on the civil voluntary actions of Christians' minds, none'. ${ }^{63}$ Calvin was especially concerned to leave room for the action of special providence and of divine grace in regeneration, which had nothing to do with the influence of the heavens. ${ }^{64}$ Hutchinson felt that astrological determinism meant men could 'excuse their vicious living by the influence and virtue of the stars, saying that they constrain them unto sin'. ${ }^{65}$ Fulke took up some of this line of argument. He quoted the widely recognized adage, 'Sapiens dominabitur astris', ${ }^{66}$ and he turned against the astrologers the words of Ptolemy which they admitted, to the effect that the stars do not compel men but 'drawe

${ }^{6} 6^{\text {Antiprognosticon contra praedictiones, sig. A6 }}{ }^{\mathrm{r}}$ : 'pulcherrima, et certissimam Astronomiae scientiam'.

if Antiprognosticon, sig. Avv.

$3^{8}$ Ibid., sigs. Avv, Bviiir

59 Ibid., sig. Cviir.

60 lbid., sig. Dviir-v.

${ }^{61}$ See Calvin, op. cit. (53), sigs. Aviir-Aviiiv, Civ-Ciiv, Dir ${ }^{r}$ Hooper, op. cit. (31), i. 332 ;

Hutchinson, op. cit. (31), p. 78 ; and (for William Perkins) Kocher, op. cit. (21), p. 216.

${ }_{62}$ The theological arguments are well summarized in Kocher, op. cit. (21), p. 215. Cf. Walker, op. cit. (55), p. 55 .

${ }_{6} 3$ James Pilkington, Works (Cambridge: Parker Society edition, 1842), p. 17.

64 Calvin, op. cit. (53), sig. Biiiiv.

65 Hutchinson, op. cit. (3I), p. 78 .

${ }_{60}$ Antiprognosticon contra praedictiones, sig. $\mathrm{D}_{4}{ }^{\mathrm{r}}$. On the popularity of the adage, see $\mathrm{T}$. $\mathrm{O}$. Wedel, The mediaeval attitude toward astrology (Yale Studies in English, vol. lx, reprinted 1968), pp. $68,135,137-8$. 
them that be wyllyng'. ${ }^{67} \mathrm{He}$ asked the man who had his nativity cast whether he therefore intended to live 'lyke a bruite beaste, that thou wylle suffer all thynges to woorke upon thee', and 'Wherefore serveth thy reason which thou dost not use ?'68 But these were as naturally the concerns of a Renaissance humanist conception of man as they were of Christian theology.

The distinctively theological argument stressed by Hooper and Calvin rested on the question of providence: it was to the effect that attention to the natural causes of the kinds of things astrologers sought to predict (health, famine, the welfare of commonwealths and rulers, etc.) detracted from the conception of these events as God's judgement on sin or blessing on righteousness. ${ }^{69}$ This was a line of thought which Fulke, significantly, did not take up. Though he did argue that trust in astrologers weakened trust in God's promises, $7^{\circ}$ and asserted that astrological knowledge neither glorified God nor profited man, 75 he had in general no hesitation in recognizing the proper place of secondary causes. Special providence bypassed natural causation only in the case of the miraculous, a category of phenomena which Fulke regarded as rare. $7^{2}$ Although he was clearly concerned to protect human will and rationality from subjection to physical causation, so far as the physical world is concerned his work contains no trace of the conceptual conflict between providence and materialistic determinism which Kocher has shown to have been a principal element in Elizabethan religious objections to astrology and other studies. 73

Fulke's immediate motive was to further the Reformation in England, for he had observed this in danger from prognostications in 1559: hence he stressed the harmfulness of astrology to commonwealths. 74 But the weight of his argument rested on the unscientific nature of astrology: he did not deny the importance of secondary causes, only that astrology provided a credible account of such causes. 75 Astrology was no science because it was not demonstrable, $7^{6}$ and 'this is common to all sciences, that they may be demonstrated'.77 Astrologers simply had no real knowledge of the causes the effects of which they pretended to predict: even if

67 Antiprognosticon, sig. Ciiir. Both these quotations were used by astrologers themselves, but in practice they treated their predictions as very probable and thought most men unlikely to be able to resist the influence of the stars.

${ }^{68}$ Antiprognosticon, sig. Ciir.

${ }^{69}$ Hooper, op. cit. (31), i. $33^{1-3}$, 308; Calvin, op. cit. (53), sigs. Ciir-Cviir; Kocher, op. cit. (2I), pp. $217-21$.

$7^{\circ}$ Antiprognosticon, sig. Diiiv.

${ }^{\pi}$ Ibid., sig. Dvv.

72 On sig. Cvir he took over from Chrysostom the argument that miraculous signs is the heavens attended the birth of Christ.

73 Kocher, op. cit. (21), chapter 5, and pp. 215-24.

74 Antiprognosticon, sig. Dir-v.

75 'For gevynge to every cause her propre effecte, yet wyll I not graunt effecte to that whiche is no cause: or if it be a cause, I will not graunt that to be the effect which they wyll have'; ibid., sig. Cir.

$7^{6} \mathrm{Ibid}$., sig. Bvir.

77 Ibid., sig. Biir. 
the influence of the stars were admitted, there was no means of telling their specific significance; the names and properties which astrologers attached to them were quite arbitrary and the whole body of astrological 'knowledge' had just been accepted uncritically from Chaldean superstition, with no basis in observation. So far from being demonstrably true, astrology in practice had shown itself to be evidently false. $7^{8} \mathrm{It}$ is characteristic of Fulke's rationalistic attitude that he did not charge the astrologers with 'Conjurynge'; 79 in a mass of incorrect predictions it was not surprising that very occasionally they succeeded in backing a winner. ${ }^{80} \mathrm{His}$ argument therefore differed radically from that of later Puritan writers who argued from the success of astrology to the satanic inspiration of the art; ${ }^{8 \mathrm{I}}$ and whereas Keith Thomas in this context denies any link between Puritanism and the growth of a modern scientific attitude, on the grounds that 'the spuriousness of astrological procedures was not the basis of the Puritans' objection', ${ }^{82}$ we should notice that in Fulke's case this was precisely his basis. His rationalism persisted into his theological writings, where he explained away an exorcism as 'no miracle, but a natural work' 83 and refuted the Catholic report of Luther's conception 'by a spirit Incubus' with the assertion that such a phenomenon was impossible. ${ }^{84}$

Fulke's rationalism is even more evident in the second area of natural philosophy into which he ventured in print: meteorology (the science which, in a Ptolemaic universe, covers all phenomena occurring between the earth and the sphere of the moon). Here he felt the need not to oppose a fatalistic determinism such as he saw in astrology, but to explain in terms of natural cause and effect phenomena which at the time were widely attributed solely to supernatural causes. Astrology and meteorology were the two fields of Elizabethan scientific thought in which the theological doctrine of providence seemed to impinge most on the problem of scientific explanation. But in both Fulke showed the same rationalistic attitude to science and that any dichotomy between the providential ordering of the natural world and explaining natural phenomena in terms of natural causation was quite foreign to his thought. 85 Rejecting astrological causes of meteorological phenomena, ${ }^{86}$ he did not, as others did, ${ }^{87}$ substitute as

;8 Ibid., sigs. Cir, Ciiiv-Cvir, Diiiir-Dvr, Cviiir. A parallel with Fulke's methods of theological argument may be drawn, in that in both cases he argues against uncritical acceptance of traditional knowledge-here the astrological system, there the tradition of the Roman church. The methods of testing such claims to knowledge differ, however, in the two contexts: astrology is open to testing by observation, theological traditions by their agreement with Scripture.

39 Ibid., sig. Dviiiv. He did admit the devilish nature of ancient prognosticators (sig. Bir).

Bo Ibid., sig. Ciiiir.

${ }^{81}$ Thomas, op. cit. (24), p. 359.

82 Ibid., p. 368 .

${ }_{3}$ Fulke, T. Stapleton and Martiall confuted (London, 1580 ), p. 75.

$8_{4}$ Fulke, An apologie of the professors of the gospel in Fraunce (Cambridge, 1586), p. 23.

85 For this dichotomy as a problem for Elizabethan theologians, see Kocher, op. cit. (2I), chapter 5. A less theoretical discussion of the question of providence is in Thomas, op. cit. (24), chapter 4 .

${ }_{86}$ Antiprognosticon, sigs. Dvir-Dviir.

37 E.g. Hooper, op. cit. (3I), i. 331, 333, 308. Cf. Thomas, op. cit. (24), p. 358; Kocher, op. cit. (21), pp. 161-2. 
sufficient explanation the mysterious providential purpose of God, but merely expounded the ordinary Aristotelian system of secondary causation.

This system and its Elizabethan variations and exponents have been fully discussed by S. K. Heninger. ${ }^{88}$ The importance of Fulke's work was in being the only properly scientific discussion of the subject in English in the sixteenth century $;^{89}$ hence the popularity of $A$ goodly gallerye until well into the seventeenth century. That Fulke sought a basis for the scientific explanation of meteorological phenomena in Aristotle's system is not unexpected. The Neoplatonic or hermetic science which others favoured shows little sign of having influenced Fulke's thought, at least at the time of his published scientific works, and he is unlikely to have found in it the kind of comprehensive explanatory system he needed. When he rejected the new astronomy (with which, by the $1570 \mathrm{os}$, he was well acquainted in both its Continental and its English exponents), he did so because it seemed to leave inexplicable so many phenomena for which an Aristotelian universe satisfactorily accounted :

I cold ... yelde my consent, if the accesse and recesse of the first movable, the alterations of the severall latitudes of the planettes, the continuall course and recurse of the sea, and blowing of the wind in all quarters of the world wold suffer me. 90

His work, however, belongs not to the Aristotelianism of the schools but to the neo-Aristotelianism of the sixteenth century, purged of scholastic commentary and, with the scope of the miraculous reduced, offering a more consistent and comprehensive system of explanation. Nor was Fulke slavishly bound to the authority of Aristotle:91 his reading in the subject was extensive92 and his method was to weigh the opinions of various authorities, ancient and modern, before reaching a conclusion. Usually in the interests of brevity he presented the reader only with his own opinion, but in some cases, notably that of the nature of the Milky

88 S. K. Heninger, $A$ handbook of Renaissance meteorology (Durham, N. Carolina, I960).

is Thomas Hill, $A$ contemplation of mysteries (London, 1571), the only other extended discussion, was both heavily dependent on Fulke and reverted to much of the superstition and marvel-mongering which Fulke endeavoured to dissipate.

9* Trinity College, Dublin, MS. 165 , fol. $117^{\mathrm{r}}$.

91 For example, on whirlwinds (A goodly gallerye, fols. $32^{\mathrm{v}}-33^{\mathrm{v}}$; cf. Aristotle, Meteorologica, III. i. $37 \mathrm{ob}-37 \mathrm{I}$ ) and on shooting stars ( $A$ goodly gallerye, fols. $7^{\mathrm{v}-8^{\mathrm{v}}}$; cf. Aristotle, Meleorologica, I. iv. 34 I b) he differed considerably from Aristotle; on lightning, while his basic theory was Aristotie's, he allowed for reflexion as Aristotle did not ( $A$ goodly gallerye, fols. $26^{\mathrm{v}}-27^{\mathrm{v}}$; cf. Aristotle, Meteorologica, II. ix. 370a); he rejected Aristotle's theory of the Milky Way in favour of one taken from Plutarch (A goodly gallerye, fols. $3^{8^{r}-40^{r}}$; cf. Aristotle, Meteorologica, I. viii, and Heninger, op. cit. [88], p. 102).

$92 \mathrm{He}$ drew copiously on the three standard works of antiquity: Aristotle, Meteorologica; Pliny, Historia naturalis; Seneca, Quaestiones naturales; though he avoided Pliny's addiction to the marvellous and was wary of Seneca's philosophy. He also drew on the opinion of other writers preserved in Plutarch (De placitis philosophorum), and on Theophrastus, Aratus of Soli, Ptolemy (Liber quadripartiti), Virgil, and (without acknowledgement, but see Heninger, op. cit. [88], pp. 102-3) Macrobius (In somnium Scipionis). Of mediaeval writers, he used Isidore of Seville, Avicenna, and Albertus Magnus; and, of Renaissance writers, Girolamo Cardano (De rerum varietale) and (without acknowledgement) Giovanni Pontano (Meteororum liber). A full bibliography of printed works on meteorology available by $155^{8}$ is given in Heninger, op. cit. (88). 
Way (where he set out nine other views before giving his own), 93 he showed his method at work. In theory he eschewed uncritical dependence on authority and insisted that authorities be tested by experiment and observation. After listing ancient writers on science who 'have taken upon them by heresaie to collect huge Volumes and those for the most part either miraculous, magicall, or oft impossible', he warned 'how writers often times deserve not all the most credite, when they forsake experiens and leane to other mens testimonies without farder examination'. This list of writers is headed by Pliny, the authority on meteorology whom Fulke used with the most care in $A$ goodly gallerye.94

In practice Fulke relied far more on authority than on observation. While he could weigh one authority against another, he was in no position to contradict or confirm by observation all the alleged observations of his predecessors. He ignored many of the more exotic of Pliny's meteorological marvels, but found it easier to seek naturalistic explanations of such phenomena as the 'marvailes of lightning', 'monstrous or prodigious rayne', and the generally accepted 'effects' of comets, 95 than to discount the reports of them. Heninger regards him as 'always the academician' who 'rarely controverted authority by empirical observation', but admits that 'the development of meteorology as an exact science was necessarily delayed until the invention of accurate measuring instruments'. ${ }^{6}$ Fulke's work was not entirely devoid of observation. Of four meteorological phenomena he gave descriptions of recent examples he had observed: the 'fire Drake' seen over the Thames in 1547 , the 'burning speares' seen in London in January 1561 , the thunder on 24 February 1562 as an example of wind direction affecting the audibility of thunder, and the burning of St Paul's steeple as evidence that thunder sets high places on fire.97 Also, in a few places, he argued from observation or experiment:98 in dealing with the properties of stones insisted he was listing only those which he had observed, and he referred to his own observation of fossilized objects. 99 Fulke's scientific interests were by no means wholly bookish, and the Fellows of St John's in ${ }_{15} 6_{5}$ complained that he filled his college room with 'connies, dogges, rattes, byrdes', presumably for purpose of observation. ${ }^{100}$ Kocher suggested that his explanation of 'wonderfull apparitions' in the sky by means of the science of optics indicates acquaintance with

${ }_{93}$ A goodly gallerye, fols. $3^{8 r}-40^{r}$.

94 Trinity College, Dublin, MS. 165 , fol. $145^{v}$.

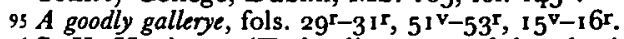

${ }^{66} \mathrm{~S}$. K. Heninger, 'Tudor literature of the physical sciences', Huntingdon Library quarterly, xxxii (1968-9), 251, 252.

$97 A$ goodly gallerye, fols. Iov, $9^{\mathrm{r}-\mathrm{v}}, 25^{\mathrm{r}}$.

${ }_{98}^{8} \mathrm{Ibid}$., fols. $2^{\mathrm{v}}$ (that watery vapours are drawn up by the sun may be proved by observing the evaporation of water from a stone), $8^{v}$ (the huge size of stars is shown to be credible by the example of the apparent size of a fire seen afar off), $49^{\mathrm{r}}$ (that rain in large drops falls from clouds close to the earth may be demonstrated by 'a playne experiment' of pouring water from different heights).

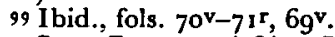

100 State Papers 12/38/1 I. II. 
the experimental work of John Dee and Leonard Digges. ${ }^{10 r}$ Fulke thought himself original in seeking natural explanations for these phenomena. ${ }^{102}$

Fulke insisted on his dissent from those who 'suppose, when any thing is derived from any naturall cause, God the chiefe and best cause of all things is excluded': natural causes and divine providence were not mutually exclusive forms of explanation. Secondary causes were not excluded by the fact that the first efficient cause of meteors was God nor by the fact that their final cause was his glory and their 'myddle endes' were 'to make the earth fruitful, to purge the ayre, to set forth [God's] power, to threaten his vengeance, to punish the world, to move to repentance'. ${ }^{03}$ Observing God's providence in the natural order was a ground for worship. ${ }^{104}$ The dragon seen over the Thames in 1547 was not the Devil but a fire drake ('nothing else but clowdes and smoake'), but it nevertheless showed that 'so mightie is God, that hee can feare his enemies with these and such like operations'. ro5 Fulke thought he could find natural causes for 'monstrous' rain (thus distinguishing it in character from the manna in Exodus, which was 'altogether miraculous'), but it still served as a portent. ${ }^{106}$ The apparitions in the clouds which he explained as optical phenomena were not, as all had hitherto thought, 'immediate miracles, without any naturall meane or cause', but this did not detract from their providential purpose 'as wonderful signes, to declare [God's] power, and to move us to amendment of life'. ${ }^{107}$ Naturalistic explanations of earthquakes and even of the destruction of Sodom and Gomorrah did not contradict the conception of these events as instruments of God's judgement. ${ }^{108}$

The proximity of meteorological phenomena to the ordinary Elizabethan's experience, and the natural and traditional association of them with immediate religious concerns made the question of providence peculiarly acute for most religious thinkers and meant that 'the position of any advocate of natural causation in meteorology was particularly difficult'.rog Fulke's confident reconciliation of the preacher's concern for the glory of God and the benefit of man with the scientist's concern for consistent explanation is therefore the more remarkable. The strictly miraculous (the phenomenon with no natural cause) had no place in his work outside Scripture, and he paid little heed to the rich fund of contemporary folk-lore relating to meteorology. ${ }^{\text {110 }}$ Only once did his book

\footnotetext{
$10 x$ Kocher, op. cit. (21), pp. 164-5.

$102 A$ goodly gallerye, fols. $44^{\mathrm{r}}-45^{\mathrm{r}}$.

so3 Ibid., fols. $44^{\mathrm{v}}, 46 \mathrm{rv}, 3^{\mathrm{v}}, 5^{\mathrm{r}}$.

104 For example, ibid., fol. $19^{\text {rv }}$, on winds.

305 Ibid., fol. I $^{\mathrm{r}}$.

${ }^{106}$ Ibid., fols. $53^{\mathrm{v}}, 5^{\mathrm{Iv}}$.

107 Ibid., fol. $44^{r}$.

108 Ibid., fols. $23^{\mathrm{v}}, \mathrm{I}_{\mathrm{v}} \mathrm{v}$.

109 Kocher, op. cit. (21), p. 162.

13. A goodly gallerye, fol. 26 .
} 
concede the use of meteorological forces to Satan, III and this in an effort to combat superstition. The lights commonly seen in churchyards and thought to be the ghosts of souls tormented in purgatory he explained as caused by the corruption of bodies, but the Devil had used them 'as strong delusions, to captive the mindes of men, with feare of the Popes Purgatorie'. ${ }^{112}$ In this field of meteorology, 'a land of fear and wonder, demon-ridden, fertile for religion and poetry, arid for science',113 a rationalistic approach could scarcely have gone further.

The pattern of whole movements of thought may not of course be deduced from the study of any one thinker. But conclusions drawn largely from religious writers who treated science only where they felt it to be threatening faith and from scientific writers who worked largely without reference to religion may well be supplemented by considering a thinker who occupied himself with both science and theology. As we might expect, the result is no simple equation of Puritan attitudes and those of the new science; movements in both science and theology were complex and a man such as Fulke had to find his own place in both. In fact, he combined in both spheres a critical attitude to all authority except the highest with a dogmatic confidence in the implications of such structures of thought and explanation as he found comprehensively satisfying. If this was not precisely what we regard as the 'scientific spirit', it was considerably closer to it than were most other Elizabethan attitudes in either science or religion.

III In orthodox thought Satan could work (natural) wonders, but not (supernatural) miracles; see Kocher, op. cit. (21), pp. 121-2, 1 24 .

${ }_{112} A$ goodly gallerye, fol. $12^{r}$.

113 Kocher, op. cit. (21), p. 162. 